\title{
RADIOMETRIC METHODS FOR THE DETERMINATIONOF MAGNESIUM AND CALCIUM IN PORTLAND CEMENT
}

\author{
by
}

Charles T. Brown

James E. Howes, Jr.

Thomas S. Elleman

Charles W. Townley

Duane N. Sunderman

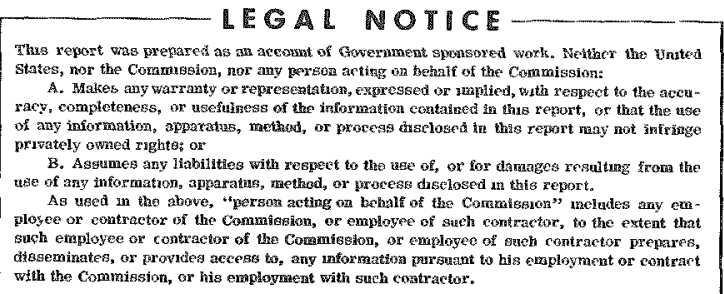

$-$

February 18, 1960

BATTELLE MEMORIAL INSTITUTE

505 King Avenue

Columbus 1, Ohio 


\section{DISCLAIMER}

This report was prepared as an account of work sponsored by an agency of the United States Government. Neither the United States Government nor any agency Thereof, nor any of their employees, makes any warranty, express or implied, or assumes any legal liability or responsibility for the accuracy, completeness, or usefulness of any information, apparatus, product, or process disclosed, or represents that its use would not infringe privately owned rights. Reference herein to any specific commercial product, process, or service by trade name, trademark, manufacturer, or otherwise does not necessarily constitute or imply its endorsement, recommendation, or favoring by the United States Government or any agency thereof. The views and opinions of authors expressed herein do not necessarily state or reflect those of the United States Government or any agency thereof. 


\section{DISCLAIMER}

Portions of this document may be illegible in electronic image products. Images are produced from the best available original document. 


\section{TABLE OF CONTENTS}

Page

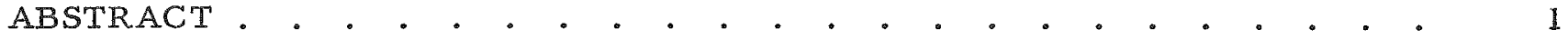

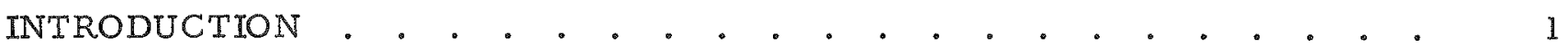

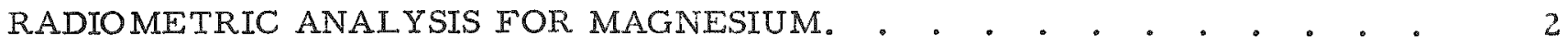

Experimental Method . . . . . . . . . . . . . . . . . 2

Apparatus and Reagents . . . . . . . . . . . . . . . 2

Procedure . . . . . . . . . . . . . . . . . . 2

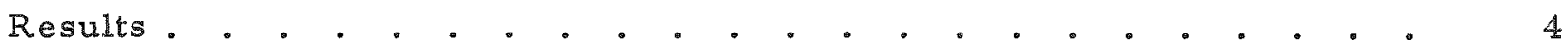

Effect of Reagent Concentration. . . . . . . . . . . . . 4

Effect of Excess $\mathrm{NH}_{4} \mathrm{OH}$. . . . . . . . . . . . . . . 5

Effect of MgO Concentration . . . . . . . . . . . . . . 5

Effect of Interfering Elements . . . . . . . . . . . . 6

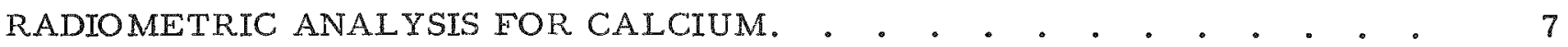

Experimental Method . . . . . . . . . . . . . . . . 7

Apparatus and Reagents . . . . . . . . . . . . . . . 7

Procedure . . . . . . . . . . . . . . . . . . 7

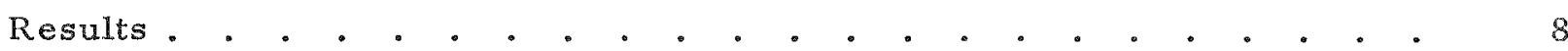

Effect of Stirring Time and $\mathrm{NH}_{4} \mathrm{OH}$ Concentration . . . . . . . 8

Effect of $\mathrm{CaO}$ Concentration . . . . . . . . . . . . . . 9

Effect of Interfering Elements . . . . . . . . . . . . . 10

DISCUSSION • •

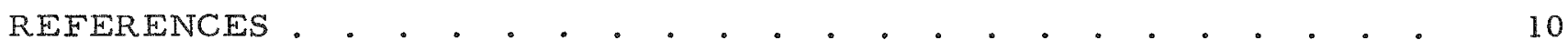




\title{
RADIOMETRIC METHODS FOR THE DETERMINATION OF MAGNESIUM AND CALCIUM IN PORTLAND CEMENT
}

\author{
Charles T. Brown, James E. Howes, Jr., Thomas S. Elleman, \\ Charles W. Townley, and Duane N. Sunderman
}

\begin{abstract}
Radiometric methods of analysis for magnesium and calcium have been developed as part of a program for the L. S. Atomic Energy Commission, Office of Isotopes Development, which are applicable to the determination of these elements in porkland cement. Both methods employ, as a precipitant, a standard solution of $\left(\mathrm{NH}_{4}\right)_{2} \mathrm{HPO}_{4}$ labeled with phosphorus-32. In the presence of $\mathrm{NH}_{4} \mathrm{OH}$, this reagent precipitates $\mathrm{Mg} \mathrm{VH}_{4} \mathrm{PO}_{4}$ or $\mathrm{Ca}_{3}\left(\mathrm{PO}_{4}\right)_{2}$ from a solution of magnesium or calcium ions. The reduction in the radioactivity level of the labeled phosphate solution afier precipitation serves as a measure of the phosphate reacted and thus a measure of the quantity of magnesium or calcium present. Studies have been made of the effects of reagent concentration, $\mathrm{VH}_{4} \mathrm{OHI}$ concentration, and other experimental variables. The interference of other elements present normally in portland cement and its raw materials has been determined. The concentration ranges for highest accuracy have been found to be 5 to $15 \mathrm{mg}$ of $11 \mathrm{gO}$ per $100 \mathrm{ml}$ and 15 to $30 \mathrm{mg}$ of CaO per $50 \mathrm{ml}$.
\end{abstract}

\section{INTRODUCTION}

The chemical analysis for magnesium and calcium is an important quality-control problem in the portland cement industry. The analytical procedure currentiy employed in the industry for magnesium, a time-consuming gravimetric method requiring the digestion, filtration, ignition, and weighing of a precipitate, is not well suited to production operations. As part of a research program for the Office of Isotopes Development, United States Atomic Energy Commission, radiometric methods for the determination of $\mathrm{MgO}$ and $\mathrm{CaO}$ in portland cement were investigated in an effort to both simplify and perform more rapidly these analytical steps.

To make the analytical technique most suitable to the needs of the industry, every effort was made during the program to adapt the radiometric methods to the equipment and procedures conventionally used for quality control in the manufacture of cement. Radiometric analytical methods for magnesium were based on the $\mathrm{MgNH}_{4} \mathrm{PO}_{4}$ precipitation method specified by the ASTM. (1) The only modification was that the $\left(\mathrm{NH}_{4}\right)_{2} \mathrm{HPO}_{4}$ was labeled with phosphorus-32 so that the radioactivity of the solution after the $\mathrm{MgNH}_{4} \mathrm{PO}_{4}$ precipitation could serve as the indicator of the amount of magnesium reacted.

Although the methods currently employed for the determination of calcium by the cement industry are simple and straightforward, the radiometric technique was developed because of the chemical similarity of calcium and magnesium, and thus the analytical application was an obvious extension of the technique developed for magnesium.

(1) References at end. 
A similar application of the radiometric titration technique to the analysis of magnesium was suggested by Langer. (2) However, this method required the addition of precipitant to a basic magnesium solution, and, as pointed out by Willard and Furman, the addition of phosphate ion to an ammonical solution tends to promote the incorporation of foreign ions in the precipitate, yielding high results. (3)

\title{
RADIOMETRIC ANALYSIS FOR MAGNESIUM
}

\author{
Experimental Method
}

\section{Apparatus and Reagents}

Radioassay Equipment. The apparatus consists of a dip-tube counter (Type 1B85, Victoreen Instrument Company) surrounded by a glass chamber of about $10 \mathrm{ml}$ in capacity. The solution which is to be radioassayed is drawn into the chamber by means of a 100-ml syringe attached to the chamber side arm. Any precipitate present is prevented from entering the chamber by means of a coarse glass frit at the bottom. The level of the solution in the radioassay chamber is adjusted to a mark on the side arm by clamping the rubber tubing between the side arm and the syringe. A schematic drawing of this equipment is shown in Figure 1.

Counting rates are measured with a Nuclear-Chicago Mode1-183 scaler. As the solution is always brought to the same level and the sample chamber and tube are fixed in position, the radioassay geometry remains constant. The chamber is flushed with the solution to be radioassayed before each determination, and the tube and chamber are surrounded by a lead shield to minimize background fluctuations.

Magnesium Oxide Solution. OThe solution is prepared by dis solving $1.000 \mathrm{~g}$ of reagent grade $\mathrm{MgO}$ in $80 \mathrm{ml}$ of $1: 3 \mathrm{HCl}$, transferring to a 1 -liter volumetric flask, and diluting to the mark. The solution is standardized gravimetrically.

Ammonium Monohydrogen Phosphate Solution. In preparing this solution, 4.000 $\mathrm{g}$ of reagent grade $\left(\mathrm{NH}_{4}\right)_{2} \mathrm{HPO}_{4}$ is dissolved in $100 \mathrm{ml}$ of water, the solution is transferred to a 1-liter volumetric flask, and is diluted to the mark. The solution is standardized gravimetrically. The standard $\left(\mathrm{NH}_{4}\right)_{2} \mathrm{HPO}_{4}$ solution is labeled with phosphorus -32 by adding 75 microcuries of phosphorus-32 in the phosphate form. This quantity of phosphorus -32 will give counting rates on the order of 8,000 to $10,000 \mathrm{cpm}$ under the conditions described in the procedure. Since phosphorus -32 has a half-1ife of 14 days, it is necessary to supplement the tracer at regular intervals if the solution is to be used over a long period of time.

\section{Procedure}

The analytical procedure used for the radiometric determination of magnesium was as follows: 


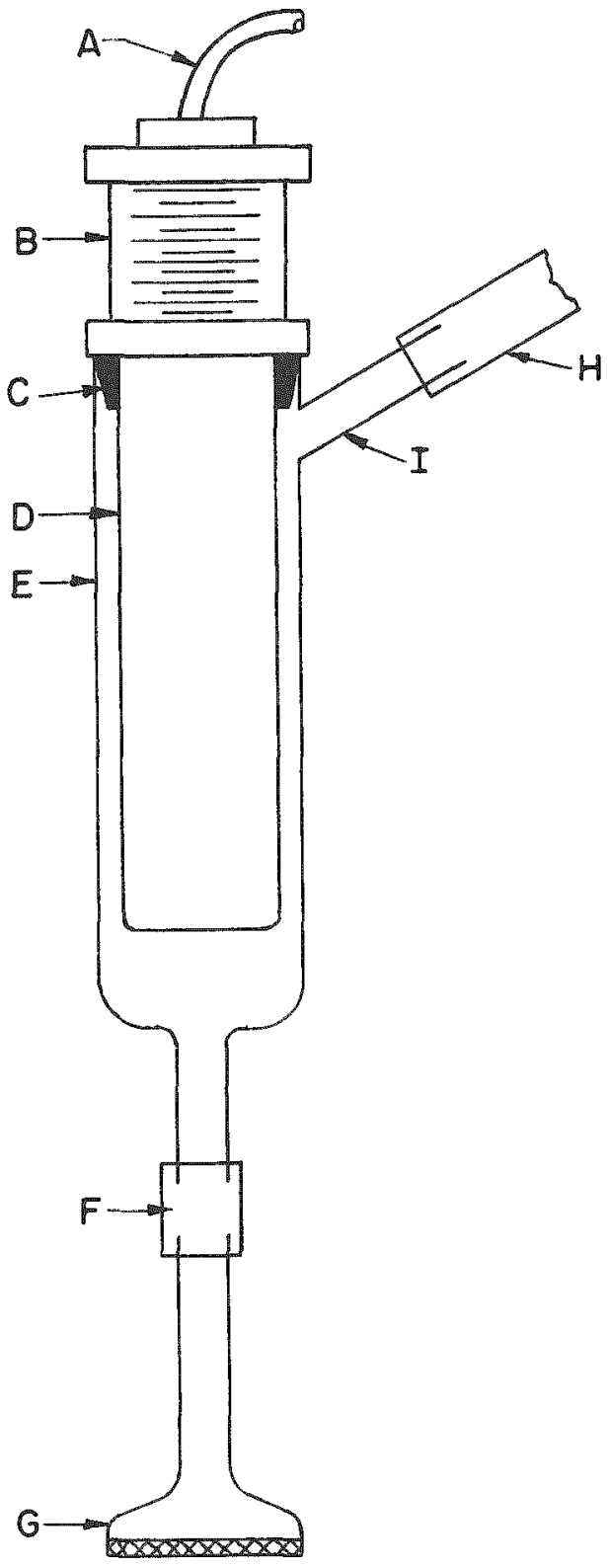

A- High-voltage lead.

F- Rubber fubing.

$B-G-M$ tube connector and socket.

G-Coarse glass frit.

$C$-Shaped rubber stopper.

$\mathrm{H}$-Rubber fubing to $100 \mathrm{ml}$ syringe.

$D-G-M$ rube, thin-wall aluminum Type 1885, Victoreen I-Glass chamber side orm. Instrument Co.

E-Glass solution chamber. 
To a solution containing approximately $10 \mathrm{mg}$ of $\mathrm{MgO}, 10 \mathrm{ml}$ of the standard $\left(\mathrm{NH}_{4}\right)_{2} \mathrm{HPO}_{4}$ solution was added. The solution was diluted to $100 \mathrm{ml}, 3$ drops of methyl red indicator were added, and the solution was then cooled in an ice bath to less than 4. $\mathrm{C}$ with continuous stirring. The frit of the radioassay assembly was placed in a position such that it was below the solution level when the sample chamber was full. The sample chamber and tube were flushed with the solution, and then refilled and radioassayed. Concentrated $\mathrm{NH}_{4} \mathrm{OH}$ was added drop by drop with stirring to the methyl red color change, then $10 \mathrm{ml}$ in excess was added. After 5 min of stirring at a temperature of less than $4 \mathrm{C}$, the sample chamber and tube were flushed again with the solution, then refilled and the radioassay was performed. In the procedure outlined, the decrease in the radioactivity level is a direct measure of the amount of phosphate reacted to precipitate $\mathrm{MgNH}_{4} \mathrm{PO}_{4}$. This measured radioactivity must be corrected for background radiation, and the counting rate after precipitation must be corrected for the dilution due to the addition of $\mathrm{NH}_{4} \mathrm{OH}$. A sample calculation follows:

Net counting rate before precipitation $=7570 \mathrm{cpm}$

Net counting rate after precipitation $=2040 \mathrm{cpm}$

Initial quantity of $\left(\mathrm{NH}_{4}\right)_{2} \mathrm{HPO}_{4}=40.0 \mathrm{mg}$

Quantity of $\left(\mathrm{NH}_{4}\right)_{2} \mathrm{HPO}_{4}$ aftex precipitation $=40.0 \times \frac{2040}{7570}=10.8 \mathrm{mg}$

$\left(\mathrm{NH}_{4}\right)_{2} \mathrm{HPO}_{4}$ reacted $=29.2 \mathrm{mg}$

Weight of $\mathrm{MgO}=29.2 \mathrm{x} \frac{\mathrm{mol} \text {. wt. } \mathrm{MgO}(40.3)}{\mathrm{mol} \text {. wt. }\left(\mathrm{NH}_{4}\right)_{2} \mathrm{HPO}_{4}(132.1)}=8.93 \mathrm{mg}$.

\section{Results}

\section{Effect of Reagent Concentration}

The effect of a large excess of $\left(\mathrm{NH}_{4}\right)_{2} \mathrm{HPO}_{4}$ on the analytical results was siudied by preparing solutions containing $9.70 \mathrm{mg}$ of $\mathrm{MgO}$ and $40,100,200$, and $300 \mathrm{mg}$ of $\left(\mathrm{NH}_{4}\right)_{2} \mathrm{HPO} 4$ in $100 \mathrm{ml}$ of solution. In each case the radiometric procedure was performed as described above. The results are summarized in Table 1.

TABLE 1. EFEEGT OF EXCESS $\left(\mathrm{NH}_{4}\right)_{2} \mathrm{HPO}_{4}$

\begin{tabular}{|c|c|c|c|c|c|}
\hline Determination & $\begin{array}{l}\left(\mathrm{NH}_{4}\right)_{2} \mathrm{HPO}_{4} \\
\text { Added, } \mathrm{mg}\end{array}$ & $\begin{array}{l}\text { Initial Solution } \\
\text { Radioassay. cpn }\end{array}$ & $\begin{array}{c}\text { Final Solution } \\
\text { Radioassay, cpm }\end{array}$ & $\begin{array}{c}\text { Change in } \\
\text { Radioassay } \\
\text { cpm }\end{array}$ & $\begin{array}{c}\text { MgO } \\
\text { Found, } \\
\text { mg }\end{array}$ \\
\hline 1. & 40.0 & 7,122 & 1,468 & 5,654 & 9.69 \\
\hline 2 & 100 & 5,058 & 3,460 & 1,598 & 9.63 \\
\hline 3 & 200 & 9,829 & 8,375 & 1,454 & 9.01 \\
\hline 4 & 300 & 14,487 & 13,050 & 1,437 & 9.07 \\
\hline
\end{tabular}


When a large excess of $\left(\mathrm{NH}_{4}\right)_{2} \mathrm{HPO}_{4}$ was used the initial counting rate was very high, and it remained high after the $\mathrm{MgNH}_{4} \mathrm{PO}_{4}$ was precipitated. The determination of $\mathrm{MgO}$ on the basis of a small difference between two large numbers is inaccurate. as can be seen from the results in Table 1. Small errors in background and dilution corrections have a greater effect on the results when the difference between the initial and final counting rates is only 10 to 20 per cent of the initial activity. An optimum value for this difference would be 50 to 75 per cent of the initial counting rate.

Effect of Excess $\mathrm{NH}_{4} \mathrm{OH}$

The optimum excess of $\mathrm{NH}_{4} \mathrm{OH}$ required to assure the complete precipitation of the $\mathrm{MgNH}_{4} \mathrm{PO}_{4}$ was determined by measuring the solubility of $\mathrm{MgNH}_{4} \mathrm{PO}_{4}$ in $100 \mathrm{ml}$ of water containing different quantities of $\mathrm{NH}_{4} \mathrm{OH}$. Labeled $\mathrm{MgNH}_{4} \mathrm{PO}_{4}$ was prepared for the study by precipitation from a solution of $100 \mathrm{mll}$ each of the standard $\mathrm{MgO}$ and $\left(\mathrm{NH}_{4}\right)_{2} \mathrm{HPO}_{4}$ solutions and $20 \mathrm{ml}$ of concentrated $\mathrm{NH}_{4} \mathrm{OH}$. The precipitate was filtered, washed with dilute $\mathrm{NH}_{4} \mathrm{OH}$, and placed in a $100-\mathrm{ml}$. volume of water and $\mathrm{NH}_{4} \mathrm{OH}$. This mixture was stirred until equilibrium was established, and the solution was radioassayed to determine the fxaction of the $\mathrm{MgNH}_{4} \mathrm{PO}_{4}$ dissolved. The experimental conditions and results are summaxized in Table 2. One determination was performed at $25 \mathrm{C}$ to illustrate the necessity of cooling the solution.

The $\mathrm{NH}_{4} \mathrm{OH}$ concentration listed in Table 2 represents the excess $\mathrm{NH}_{4} \mathrm{OH}$ added after the methyl red color change. At least $5 \mathrm{ml}$ of excess $\mathrm{NH}_{4} \mathrm{OH}$ should be added to assure complete precipitation. The addition of $2.5 \mathrm{~g}$ of $\mathrm{NH}_{4} \mathrm{NO}_{3}$ to the solution containing an $\mathrm{NH}_{4} \mathrm{OH}$ excess of $10 \mathrm{ml}$ did not appreciably decrease the solubility of the $\mathrm{MgNH}_{4} \mathrm{PO}_{4}$.

TABLE 2. EFFECT OF $\mathrm{NH}_{4}$ OH CONCENTRATION AND TEMIPERATURE ON THE SOLUBILIT Y OT MgNI $\mathrm{PO}_{4}$

\begin{tabular}{|c|c|c|c|c|}
\hline Tempciaure, C & $\begin{array}{l}\text { Volume of } \\
\mathrm{NH}_{4} \mathrm{OH}_{9} \mathrm{mI}\end{array}$ & $\begin{array}{l}\text { Radioassay of } \\
\text { Sulution, cpm }\end{array}$ & $\begin{array}{c}\text { Theoretical } \\
\text { 16u Per Cent } \\
\text { Sulubulity, cpm }\end{array}$ & $\begin{array}{l}\text { Solublity, } \\
\text { per cent }\end{array}$ \\
\hline 25 & 0 & 477 & 17.400 & 2.74 \\
\hline 4 & $n$ & 289 & 17,400 & 1.66 \\
\hline 4 & 2 & 95 & $17,4(11)$ & 1.55 \\
\hline 4 & 5 & 66 & 17,400 & 11.38 \\
\hline 4 & 10 & 91 & $17, \pm 40$ & 0.52 \\
\hline 2 & $\begin{array}{l}10+2.5 g \\
\text { of } \mathrm{NH}_{4} \mathrm{NO}_{3}\end{array}$ & 82 & 17,400 & 0.47 \\
\hline
\end{tabular}

\section{Effect of MgO Concentration}

The accuracy of the procedure over a MgO concentration range of 1 to $25 \mathrm{mg}$ per $100 \mathrm{ml}$ was studied by performing $\mathrm{MgO}$ determinations on solutions containing nominal $\mathrm{MgO}$ concentrations of $1 \mathrm{mg}$ per $100 \mathrm{ml}, 5 \mathrm{mg}$ per $100 \mathrm{ml}, 10 \mathrm{mg}$ per $100 \mathrm{ml}$, and $25 \mathrm{mg}$ per $100 \mathrm{ml}$. The results of these determinations are summarized in Table 3. 
The precision and accuracy of the $\mathrm{MgO}$ determinations are within 1 per cent except for the nominal $\mathrm{MgO}$ concentration of $1 \mathrm{mg}$ per $100 \mathrm{ml}$. The lower limit for the MgO concentration should be taken as $5 \mathrm{mg}$ per $100 \mathrm{ml}$ for accurate results.

TABLE 3. PRECISION AND ACCURACY OF MgO DETERMINATIONS AS A FUNCTION OF MgO CONCENTRATION

\begin{tabular}{|c|c|c|c|c|}
\hline \multicolumn{3}{|c|}{ Mgo Concentration, mg per $100 \mathrm{~m} 1$} & \multirow{2}{*}{$\begin{array}{c}\text { Standard } \\
\text { Deviation, } \\
\text { mg Mgo }\end{array}$} & \multirow{2}{*}{$\begin{array}{c}\text { Absulute } \\
\text { Error, } \\
\text { per cent }\end{array}$} \\
\hline Theoretical & Experimental & $\begin{array}{c}\text { Experimental } \\
\text { Average }\end{array}$ & & \\
\hline \multirow[t]{3}{*}{0.97} & 0.90 & & & \\
\hline & 0.95 & & & \\
\hline & 0.89 & 0.91 & \pm 0.026 & 6.19 \\
\hline \multirow[t]{4}{*}{4.85} & 4.86 & & & \\
\hline & 4.88 & & & \\
\hline & 4.84 & & & \\
\hline & 4.82 & 4.85 & \pm 0.022 & 0.10 \\
\hline \multirow[t]{5}{*}{9.70} & $9.93(a)$ & & & \\
\hline & 9.68 & & & \\
\hline & 9.70 & & & \\
\hline & 9.72 & & & \\
\hline & 9.78 & 9.72 & \pm 0.030 & 0.21 \\
\hline \multirow[t]{4}{*}{24.25} & 24.51 & & & \\
\hline & 24.55 & & & \\
\hline & 24.32 & & & \\
\hline & 24.31 & 24.42 & \pm 0.11 & 0.70 \\
\hline
\end{tabular}

(a) Determination excluded since its deviation from the average of the other four is more than four times thetr average deviation.

\section{Effect of Interfering Elements}

The effect of interfering elements on the radiometric method of analysis for magnesium was investigated. Samples containing $10 \mathrm{mg}$ of $\mathrm{MgO}$ and $10 \mathrm{mg}$ of a specific contaminant in $100 \mathrm{ml}$ of solution were run under the normal experimental conditions. The following contaminants were used: $\mathrm{Al}_{2}\left(\mathrm{SO}_{4}\right)_{3}, \mathrm{CaCl} 2, \mathrm{Fe}\left(\mathrm{NO}_{3}\right)_{3}, \mathrm{MnSO}_{4}, \mathrm{NaCl}$, and $\mathrm{KCl}$. Calcium and manganese were the only elements found to interfere. The MgO results were 17 per cent high with the calcium present and 14 per cent high with the manganese present. Two-milligram quantities of $\mathrm{MnSO}_{4}$ and $\mathrm{CaCl}_{2}$ per $10 \mathrm{mg}$ of $\mathrm{MgO}$ in $100 \mathrm{ml}$ of solution did not interfere, while 4 -mg quantities of these same two compounds per $10 \mathrm{mg}$ of $\mathrm{MgO}$ yielded results 3 per cent high in the case of manganese and 8 per cent high in the case of calcium.

In a typical cement sample only $0.25 \mathrm{mg}$ of $\mathrm{Mn}_{2} \mathrm{O}_{3}$ will be present for each $10 \mathrm{mg}$ of $\mathrm{MgO}$; so interference due to manganese is no problem. However, CaO is present in a ratio of about $265 \mathrm{mg}$ of $\mathrm{CaO}$ to $10 \mathrm{mg}$ of $\mathrm{MgO}$. In this latter case a separation must be effected before the magnesium is determined. 


\section{RADIOMETRIC ANALYSIS FOR CALCIUM}

\section{Experimental Method}

\section{Apparatus and Reagents}

Radioassay Equipment. The apparatus employed in the calcium analysis is the same as that described for use in the magnesium analysis. The same sample chamber, dip counter, and scaling equipment are used.

Calcium Nitrate Solution. The solution is prepaxed by dissolving $5.90 \mathrm{~g}$ of reagent grade $\mathrm{Ca}\left(\mathrm{NO}_{3}\right) 2 \cdot 4 \mathrm{H}_{2} \mathrm{O}$ in $100 \mathrm{ml}$ of water, transfer $\mathrm{ring}$ to a 1 -1iter volumetric flask, and diluting to the mark. The solution is standardized gravimetrically.

Ammonium Monohydrogen Phosphate Solution. The $\left(\mathrm{NH}_{4}\right)_{2} \mathrm{HPO}_{4}$ solution is prepared in the same manner as described for the magnesium procedure, except only 30 microcuries of phosphorus -32 is used to label the phosphate. Under the conditions described for the calcium determination this quantity of phosphorus -32 will give counting rates on the order of 8,000 to $10,000 \mathrm{cmm}$.

\section{$\underline{\text { Procedure }}$}

The analytical procedure used for the radiometric determination of calcium was as follows:

Ten millilitex of the standard ( $\left.\mathrm{NH}_{4}\right) 2 \mathrm{HPO}_{4}$ solution was diluted to $40 \mathrm{ml}$, the sample chamber and counting tube were flushed with this solution, the chamber was refilled, and the solution was radioassayed. Approximately $15 \mathrm{mg}$ of CaO and 2 to 5 drops of concentrated $\mathrm{NH}_{4} \mathrm{OH}$ were added. (All calculations of calcium concentration have been made on the basis of $\mathrm{CaO}$.$) After 15$ min of stirxing at room temperature, the sample chamber and tube were flushed again with the solution, refilled, and radioassayed.

Under this procedure, the fraction of the radioactivity remaining in solution after the precipitation of $\mathrm{Ca}_{3}\left(\mathrm{PO}_{4}\right)_{2}$ represents the fraction of the $\left(\mathrm{NH}_{4}\right)_{2} \mathrm{HPO}_{4}$ unreacted. The counting rates must be corrected for background radiation, and the counting rate after precipitation must be corrected for dilution due to the addition of the CaO solution. A sample calculation follows:

Net counting rate before precipitation $=8234 \mathrm{cpm}$

Net counting rate after precipitation $=2795 \mathrm{cpm}$

Initial quantity of $\left(\mathrm{NH}_{4}\right)_{2} \mathrm{HPO}_{4}=40.00 \mathrm{mg}$ 
Quantity of $\left(\mathrm{NH}_{4}\right)_{2} \mathrm{HPO}_{4}$ after precipitation $=40.00 \times \frac{2795}{8234}=13.57 \mathrm{mg}$

$\left(\mathrm{NH}_{4}\right)_{2} \mathrm{HPO}_{4}$ reacted $=26.43 \mathrm{mg}$

Weight of $\mathrm{CaO}=26.43 \times \frac{3 \times \mathrm{mol} . \mathrm{wt} \cdot \mathrm{CaO}(56.08)}{2 \mathrm{xmol} \cdot \mathrm{wt} \cdot\left(\mathrm{NH}_{4}\right) \mathrm{HPO}_{4}(132.1)}=16.83 \mathrm{mg}$.

The difference between the initial and final counting rates should be 50 to 75 per cent of the initial counting rate for optimum accuracy in the results; so a sufficient excess of $\left(\mathrm{NH}_{4}\right)_{2} \mathrm{HPO}_{4}$ should be used to give this difference.

\section{Results}

Effect of Stirring Time and $\mathrm{NH}_{4} \mathrm{OH}$ Concentration

Studies were performed to determine the optimum stiring time and $\mathrm{NH}_{4} \mathrm{OH}$ concentration required to yield accurate results in the CaO determination. The quantity of concentrated $\mathrm{NH}_{4} \mathrm{OH}$ added to the solution was varied from 0 to $1.0 \mathrm{ml}$, and the analysis was performed as described in the procedure. The results of these determinations are given in Table 4. Included also in the table are the results of determinations made with stirring times of $1,5,10,15$, and $20 \mathrm{~min}$ with a constant $0.1-\mathrm{ml}$ volume of concentrated $\mathrm{NH}_{4} \mathrm{OH}$. A $16.66-\mathrm{mg}$ quantity of $\mathrm{CaO}$ was used in each analys is.

TABLE 4. EFFECT OF $\mathrm{NH}_{4}$ OH CONCENTRATION AND STIRRING TIME ON THE CAO DETERMINATION

\begin{tabular}{lccc}
\hline \hline $\begin{array}{c}\text { Volume of } \\
\mathrm{NH}_{4} \mathrm{OH}_{8} \mathrm{ml}\end{array}$ & $\begin{array}{c}\text { Stiring Time, } \\
\text { min }\end{array}$ & $\begin{array}{c}\text { CaOFound } \\
\text { mg }\end{array}$ & $\begin{array}{c}\text { Absolute Error, } \\
\text { per cent }\end{array}$ \\
\hline 0 & 15 & 12.19 & 26.8 \\
0.05 & 15 & 16.29 & 2.3 \\
0.1 & 1 & 16.95 & 1.7 \\
& 5 & 16.90 & 1.4 \\
& 10 & 16.95 & 1.7 \\
& 15 & 16.70 & 0.2 \\
& 20 & 16.66 & 0.0 \\
0.2 & 15 & 16.55 & 0.7 \\
0.5 & 15 & 16.80 & 0.8 \\
1.0 & 15 & 16.40 & 1.6 \\
\hline
\end{tabular}


The absolute error in the analysis of $\mathrm{CaO}$ was found to be as high as $26.8 \mathrm{pur}$ cont when no $\mathrm{NH}_{4} \mathrm{OH}$ was added, but only a few drops of concentrated $\mathrm{NH}_{4} \mathrm{OH}$ are necessary to reduce this error to less than 1 per cent. The $\mathrm{NH}_{4} \mathrm{OH}$ is apparently necessary to shift the phosphate equilibrium in solution toward the $\mathrm{PO}_{4}^{-3}$ ion and to thus obtain complete precipitation of the calcium as $\mathrm{Ca}_{3}\left(\mathrm{PO}_{4}\right)_{2}$. The best rusults were achieved with 0.1 to $0.2 \mathrm{ml}$ (2 to 5 drops) of concentrated $\mathrm{NH}_{4} \mathrm{OH}$. A stirring time of at least $15 \mathrm{~min}$ was found necessary to attain equilibrium between the solution and precipitate and to thus obtain accurate results.

\section{Effect of CaO Concentration}

The accuracy of the radiometric procedure was studied over a CaO concontration range of 3 to $33 \mathrm{mg}$ per $50 \mathrm{ml}$. Analyses were performed under the same expurimanial conditions and with a constant percentage excess of $\left(\mathrm{NH}_{4}\right)_{2} \mathrm{HPO}_{4}$. The Car concentrations studied were $3.33,8.33,10.00,13.32,16.66$, and $33.32 \mathrm{mg}$ per $50 \mathrm{ml}$. The results of these determinations are given in Table 5.

TABLE 5. PRFCISION AND ACCURACY OF CAO DETERMINATIONS AS A EUNCTIONOF CAO CONCENTRATIOR

\begin{tabular}{|c|c|c|c|c|}
\hline \multicolumn{3}{|c|}{ CaO Guncentration, ny per $50 \mathrm{ml}$} & \multirow{2}{*}{$\begin{array}{c}\text { Standard } \\
\text { Deviation, } \\
\text { ing CaO }\end{array}$} & \multirow{2}{*}{$\begin{array}{l}\text { Abolute } \\
\text { Erroi, } \\
\text { pet c cnt }\end{array}$} \\
\hline Theoretical & Expeimental & $\begin{array}{c}\text { Cxpe limental } \\
\text { Average }\end{array}$ & & \\
\hline \multirow[t]{2}{*}{3.33} & 2.94 & & & \\
\hline & 2.83 & 2.88 & \pm 01.8 & 13.5 \\
\hline \multirow[t]{2}{*}{8.33} & 7.86 & & & \\
\hline & 7.98 & 7.42 & \pm 6.68 & t. \\
\hline \multirow[t]{3}{*}{10.100} & 9.31 & & & \\
\hline & 9.91 & & & \\
\hline & 19.89 & 9.70 & $t 0.3 t$ & 3.6 \\
\hline \multirow[t]{3}{*}{13.32} & $13.30^{\circ}$ & & & \\
\hline & 13.30 & & & \\
\hline & 13.17 & 13.28 & 50.10 & 0.3 \\
\hline \multirow[t]{8}{*}{16.66} & 16.63 & & & \\
\hline & 16.60 & & & \\
\hline & 16.81 & & & \\
\hline & 16.80 & & & \\
\hline & 16.63 & & & \\
\hline & 16.60 & & & \\
\hline & 16.67 & & & \\
\hline & 16.68 & 16.67 & +0.08 & 0.06 \\
\hline \multirow[t]{3}{*}{33.32} & .33 .26 & & & \\
\hline & 33.92 & & & \\
\hline & 33.39 & 33.52 & \pm 0.35 & 0.6 \\
\hline
\end{tabular}

The precision and accuracy of the CaO determinations were within 1 per cent for CaO concentrations higher than $13 \mathrm{mg}$ per $50 \mathrm{ml}$. The lower limits for the CaO concertration should be taken as $15 \mathrm{mg}$ per $50 \mathrm{ml}$ for accurate results. 


\section{Effect of Interfering Elements}

The effect of interfering elements on the radiometric method of calcium analysis was investigated. A CaO concentration of $16.66 \mathrm{mg}$ per $50 \mathrm{ml}$ was used, and other experimental conditions were the same as those described in the procedure. In each determination the concentration of contaminant was maintained at approximately the same order of magnitude as would be expected in a sample of portland cement. The following contaminants were used: $\mathrm{Al}\left(\mathrm{NO}_{3}\right)_{3}, \mathrm{MgO}, \mathrm{Fe}\left(\mathrm{NO}_{3}\right)_{3}, \mathrm{MnSO}_{4}$, and $\mathrm{K}_{2} \mathrm{SO}_{4}$. The elements found to interfere were aluminum, iron, and magnesium. The CaO results were 6 per cent high with $1 \mathrm{mg}$ of iron present, 13 per cent high with $1 \mathrm{mg}$ of magnesium, and 9 per cent high with $1 \mathrm{mg}$ of aluminum.

Manganese did not interfere even at a concentration 20 times that found in a typical cement sample. The interference of aluminum, iron, and magnesium is a problem, however, and the calcium must be separated from these elements before an analysis is performed.

\section{DISCUSSION}

The accuracy and precision of the radiometric procedures developed for the determination of magnesium and calcium in portland cement are within 1 per cent. For these analytical methods, the recommended concentration ranges are 5 to $15 \mathrm{mg}$ of $\mathrm{MgO}$ per $100 \mathrm{ml}$ and 15 to $30 \mathrm{mg}$ of $\mathrm{CaO}$ per $50 \mathrm{ml}$.

The primary advantages of the radiometric methods are speed and simplicity. Excluding the necessary separations of interfering ions, a magnesium or calcium determination may be made in less than $1 \mathrm{hr}$. There is no need for close pH control or the preparation and storage of a large number of standard solutions. The apparatus is simple and easy to maintain, and a laboratory technician with analytical experience could easily adapt himself to radioassay techniques.

The only other magnesium or calcium method that compares to the radiometric. method in simplicity and speed is the EDTA titration with an Eriochrome Black $\mathrm{T}$ indicator. (4) Here, as in most EDTA titrations, pH is very important and properly controlled buffering must be employed. Special precautions must be taken to mask interfering elements, and complexing agents must be added to prevent the precipilation of metal hydroxides of such elements as aluminum and iron, since the titrations are carried out at $\mathrm{pH} 10$.

\section{REFERENCES}

(1) ASTM Standards on Cement, American Society for Testing Materials, Philadelphia (1955).

(2) Langer, A. "Radiometric Titration of Magnesium", J. Phys. Chem., 45, 639 (1941). 
(3) Willard, H. H., and Furman, N. H., Elementary Quantitative Analysis, 3rd edition, D. Van Nostrand Company, New York (1950), p 331.

(4) Dieh1, H., Goetz, C. A., and Hach, C. C., "The Versenate Titration for Total. Hardness", J. Am. Water Works Assoc., 42, 40 (1950). 